Original Article

Received/Accepted

Dates

19.04.2021/21.05.2021

DOI

10.52096/jsrbs.6.1.7.13.12
Journal of Social Research and Behavioral Sciences

Sosyal Araştırmalar ve Davranış Bilimleri Dergisi

ISSN:2149-178X

Volume: 7 Issue: 13 Year: 2021

\title{
Hayat Bilgisi Ders Kitaplarında Yer Alan Soruların Eleştirel Düşünmeye Katkısının Öğretmen Görüşlerine Göre İncelenmesi
}

\author{
Murat ŞAHIN \\ İstanbul Üniversitesi Cerrahpaşa \\ Lisansüstü Eğitim Enstitüsü \\ muratefe451@gmail.com \\ ORCID: 0000-0001-8960-5636
}

\section{Özet}

$\mathrm{Bu}$ araştırmanın amacı, Hayat Bilgisi ders kitaplarında yer alan soruların eleştirel düşünmeye katkısını öğretmen görüşlerine göre incelemektir. Araştırmada nitel araştırma yöntemlerinden durum çalışması deseni kullanılmıştır. Araştırmanın çalışma grubunu 2018-2019 eğitim-öğretim yılında Van ilinde görev yapmakta olan 12 sınıf öğretmeni oluşturmaktadır. Çalışma grubunun belirlenmesinde amaçlı örnekleme yöntemlerinden, ölçüte dayalı örnekleme yöntemi kullanılmıştır. Veriler araştırmacı tarafindan geliştirilen yarı yapılandırılmış görüşme formu ile toplanmıştır. Verilerin analizinde içerik analizi yöntemi kullanılmıştır. Araştırma sonunda elde edilen bulgular şunlardır: 1- Sınıf öğretmenleri eleştirel düşünme becerisine sahip bireyleri sorgulayıcı, farklı bakış açısına sahip, problemlere çözüm üretebilen, bilgiyi özümseyen, analiz ve değerlendirme yapabilen bireyler olarak görmektedirler. 2- Birinci sınıf öğretmenleri, Hayat Bilgisi ders kitaplarında yer alan soruların öğrencilerin eleştirel düşünme becerisine olumlu katk1 sağladığını belirtirken ikinci ve üçüncü sınıf öğretmenleri katkı sağlamadığını belirtmişlerdir. 3- Sınıf öğretmenlerinin tamamı Hayat Bilgisi ders kitaplarında yer alan soruların öğrencilerin eleştirel düşünme becerilerine daha fazla katkı sağlayabilmesi için soru sayısının artırılmasını ve soruların gerçek hayat ile ilişkilendirilmesi önermişlerdir.

Anahtar Kelimeler: Hayat Bilgisi Dersi, Eleştirel Düşünme, Ders Kitabı. 


\title{
Investigation of Contributions of The Questions in Life Science Course Books to Critical Thinking According to The Views of Teachers
}

\begin{abstract}
The aim of this study is to examine the contribution of the questions in the Life Science course books to critical thinking according to the views of teachers. A case study pattern, which is one of the qualitative research methods, was used in the research. The study group consists of 12 Classroom Teachers working in the province of Van in the 2018-2019 academic year. In order to determine the study group, criterion based sampling method was used. Data were collected by semi-structured interview form developed by the researcher. Content analysis method was used for data analysis. The findings obtained at the end of the research are as follows: 1- Classroom teachers see individuals with critical thinking skills as inquiring, having a different perspective, producing solutions to problems, assimilating information, and making analysis and evaluation. 2- While the first grade teachers stated that the questions in the Life Studies textbooks contributed positively to the critical thinking skills of the students, the second and third grade teachers stated that they did not. 3- All of the classroom teachers suggested increasing the number of questions and linking the questions with real life so that the questions in the Life Studies textbooks could contribute more to the critical thinking skills of the students.
\end{abstract}

Key Words: Life Science Curriculum, Critical Thinking, Course Book.

\section{Giriş}

Öğrencilerin temel bilgi, beceri, tutum ve değerleri kazanmalarını sağlayan derslerin başında Hayat Bilgisi dersi gelmektedir. Hayat Bilgisi dersi ilkokulun ilk üç yılında okutulan ve öğrencinin etrafında gelişen olayları anlamasına yardımcı olan temel bir derstir (Aladağ, 2016: 20). Hayat Bilgisi dersi ilkokul eğitiminin bu döneminde mihver ders olma özelliği göstermektedir. Çünkü Hayat Bilgisi dersi çocukların yaratıcılık ve eleştirel düşünmeyi alışkanlık haline getirmesini amaçlayan, temel olarak çocukların bilgi ve beceri ile donatılmasına, toplumsal yaşama uyumlu bireyler olmasına yardımcı olan derslerin başında gelmektedir ve diğer dersler de bu ders ekseninde şekillenmektedir (Şimşek, 2005: 15). Diğer derslerin tanıtılmasında ve önemlerinin ifade edilmesinde Hayat Bilgisi dersi pratik ve kalıcı uygulamalar sunmaktadır. Bu nedenle Hayat Bilgisi dersi bir yaşam, deneme, gözlem ve iş dersidir. Yaşanılarak kazanılan bilgilerin, hayat boyu devam ettiği ve kolay kolay unutulmadığg düşünüldüğünde bu durum daha rahat anlaşılabilmektedir (Güngördü, 2002: 45). 
Hayat Bilgisi dersi bireylerin eğitim hayatlarının ilk yıllarından itibaren edinmeleri gereken en temel yaşam becerilerin yanında kendini tanıyan, sağlıklı ve güvenli bir yaşam süren, yaşadığı toplumun değerlerini özümseyen, doğaya ve çevreye duyarlı, araştıran, üreten ve ülkesini seven bireyler olarak yetişmelerini amaçlamaktadır (MEB, 2018: 8). Bu amaç doğrultusunda Hayat Bilgisi dersi yaşam becerileri ve kavramlardan oluşan kapsamlı bir program çerçevesinde birçok kazanımı çocuklara aktarmayı hedeflemektedir. Bu kazanımlardan günlük hayatta en fazla kullanılanları ise düşünme, problem çözme ve iletişim becerileridir (Akçay, Kapıcı, 2016: 115). Belirtilen bu üç becerinin temel bir unsuru eleştirel düşünme becerisidir. Eleştirel düşünme becerisi gerçekleri analiz etme, düşünceleri üretip düzenleme, karşılaştırma yapma, çıkarımlar yapma, savları değerlendirme ve sorun çözme becerilerinin bir bütünü olarak ifade edilebilir (Marrapodi, 2003: 19). Eleştirel düşünme becerisi çocukların bireysel özerklik kazanmalarına, toplumda sosyal sorunların çözümünde bilgili insanlar olarak yer almalarına, demokratik ve doğal hakları savunmalarına ve çalışma alanında kolay bir biçimde ilerlemelerine katkı sağlamaktadır (Yıldırım, Yalçın, 2008:175).

Eleştirel düşünme becerisi bireylerin yaşamlarına bu kadar fazla katkı sağlamasına rağmen bu becerinin öğretilebilirliği konusunda hala yanlış bir takım varsayımlar mevcuttur. Özellikle toplumda eleştirel düşünme becerisinin öğretilebilirliği konusundaki bu anlayışlar temelsiz varsayımlardan ibarettir. Bu varsayımlardan bazıları eleştirel düşünmenin zekâyla bağlantılı olduğu ve öğretilebilir bir beceri olmadığı şeklindedir. Ancak bu varsayımların aksine eleştirel düşünme becerileri öğretilebilir becerilerdir. Zihinsel disiplin kuramının temellerini atan Platon, düşünmenin öğretilebilecek bir beceri olduğunu ve bunun eğitimin belli başlı amaçlarından biri olduğunu vurgulamaktadır. Literatürde Plato'nun bu görüşünü destekleyen birçok araştırma mevcuttur. Özellikle 1983, 1986 ve 1993 yıllarında yapılan bazı deneysel araştırmalar eleştirel düşünme becerisi dersini alan öğrencilerin diğer öğrencilere kıyasla problem çözme gibi birçok alanda diğer öğrencilere göre daha başarılı olduklarını ve öğrendikleri bu becerileri okul dışında da kullanabildiklerini göstermiştir (Halpern 2003:85).

Öğretilebilir bir beceri olan eleştirel düşünme becerisinin erken yaşlarda kazandırılması, ilerleyen yaşlara göre daha kolaydır (Aybek, 2010:18). Bu nedenle öğrencilere erken yaşlardan itibaren bu becerilerin kazandırılacağı eğitim ortam ve materyallerinin sunulması önemlidir. Bu tarz eğitim ortamlarında uygun ders materyalleri ile öğrencilerin düşünme süreçlerinin takip edilmesi, 
işbirlikçi düşünmelerinin desteklenmesi, cevaplardan daha ziyade soru sormalarına ve farklı bakış açısı kazanmalarına yönelik etkinliklerin yapılması öğrencilerin eleştirel düşünme becerisi kazanmalarına olumlu katkı sağlayacaktır. Öğrencilerin eleştirel düşünme becerisi kazanmalarında önemli bir rol oynayan eğitim ortam ve materyallerinin bu bakış açısı ile hazırlanması bu anlamda çok önemsenmektedir.

Eleştirel düşünme becerilerinin öğrencilere kazandırılmasında kullanılan eğitim materyallerinin başında ders kitapları gelmektedir. Ders kitaplarında yer alan çalışmaların bu becerileri kazandırabilme noktasında ele alınarak incelenmesi belirlenen hedeflere ulaşılması konusunda fayda sağlayacaktır. Özellikle öğrenciler bir problem karşısında çok yönlü düşünerek çözüm yolları aradıklarında problem çözme ve eleştirel düşünme becerileri gelişmektedir (Ersoy, Başer, 2011: 9). Bu nedenle Hayat Bilgisi ders kitaplarındaki soruların öğrencilerin eleştirel düşünme becerisinin gelişimi üzerindeki etkisi daha dikkatli incelenmelidir. İlkokulun ilk üç sınıfında okutulan Hayat Bilgisi ders kitaplarında yer alan soruların eleştirel düşünmeye ne düzeyde katkı sağladığının tespit edilmesi hem alana katkı sağlayacaktır hem de hazırlanmış olan kitaplar için geri dönüt imkânı sunacaktır. Bu amaç doğrultusunda bu çalışmada Hayat Bilgisi ders kitaplarında yer alan soruların eleştirel düşünmeye katkısı sınıf öğretmenlerinin görüşleri doğrultusunda incelenmiştir. Araştırmada kullanılan yarı yapılandırılmış görüşme formunda yer alan ve öğretmen adaylarına yöneltilen sorular şu şekildedir:

1- Eleştirel düşünme sizin için ne ifade etmektedir?

2- Hayat Bilgisi ders kitaplarında yer alan soruların öğrencilerin eleştirel düşünme becerisine katkısı hakkında ne düşünüyorsunuz?

3- Hayat Bilgisi ders kitaplarında yer alan soruların öğrencilerin eleştirel düşünme becerisine katkısının artırılmasına yönelik önerileriniz nelerdir?

\section{Araştırmanın Yöntemi}

Araştırmada nitel araştırma yöntemlerinden durum çalışması (case study) deseni kullanılmıştır. Durum çalışmaları, 'nasıl' ve 'niçin' sorularını temel almakta ve araştırmacının kontrol edemediği bir olgu ya da olayın derinliğine incelenmesine olanak tanımaktadır (Yıldırım, Şimşek 2005:292). 
Araştırmanın çalışma grubu nitel araştırma yaklaşımı içinde yer alan amaçlı örnekleme yöntemlerinden ölçüt örnekleme yoluyla belirlenmiştir (Yıldırım, Şimşek, 2005:89). Bu amaçla katılımcıların belirlenmesinde, araştırmaya gönüllü katılım ve ilkokul birinci, ikinci veya üçüncü sınıflarda görevli sınıf öğretmeni olma biçiminde iki temel ölçüt dikkate alınmıştır. Araştırmaya 2018-2019 eğitim öğretim yılı bahar döneminde Van ilindeki dört devlet ilkokulunda sınıf öğretmeni olarak görev yapan 12 sınıf öğretmeni katılmıştır. Araştırmaya katılan öğretmenlerin 3'ü erkek ve 9'u kadındır. Çalışma grubundaki öğretmenlerden sadece biri lisansüstü eğitim düzeyine sahiptir. Öğretmenlerin mesleki kıdemleri 20 yılın altındadır. Çalışmada birinci sınıf öğretmenleri (A) harfi, ikinci sınıf öğretmenleri (B) harfi ve üçüncü sınıf öğretmenleri (C) harfi ile kodlanmıştır.

Çalışmada veri toplama aracı olarak yarı yapılandırılmış görüşme formu kullanılmışıı. Görüşme sırasında alternatif ve sonda sorular sorularak görüşme soruları zenginleştirilmiş̧ir. Görüşme soruları literatür taramasından sonra uzman görüşü alınarak düzenlenmiştir. Görüşme formunda yer alan toplam altı soru uzman düzeltmeleri sonucu üçe indirilmiş ve içerik geçerliliği sağlanmıştır. Görüşmeler 2018-2019 eğitim öğretim yılının ikinci döneminde katılımcıların kendi okullarında gerçekleştirilmiş̧ir. Görüşmeler ortalama 20 dakika ile 40 dakika arasında değişen sürelerde yapılmıştır. Görüşme sırasında veri kaybını önlemek amacıyla görüşmeler ses kayıt cihazına kaydedilmişsir.

Araştırmacı tarafından ses kayıt cihazına kaydedilen veriler önce bilgisayar ortamında yazılı hale getirilmiş ve daha sonra nitel araştırma tekniklerden içerik analizi kullanılarak çözümlenmiştir. Öğretmenlerin verdikleri cevaplar araştırmacı tarafindan incelenerek kodlanmış ve çalışmanın güvenilirliğini arttırmak amacıyla bir uzmanın veri üzerindeki çözümlemeleri dikkate alınarak benzerliklerine göre gruplandırılmıştır. Yapılan bu işlem sırasında Miles ve Huberman'ın (1994:46) önerdiği güvenirlik formülü kullanılmış ve araştırmanın güvenirliği \% 92 olarak hesaplanmıştır. Daha sonra öğretmenlerin görüşlerini destekleyen alıntıların seçimi yapılarak araştırma bulgularının yazımına geçilmiştir. 


\section{Bulgular}

Öğretmenler ile yapılan görüşmeler neticesinde toplanan veriler incelenmiş ve Hayat Bilgisi ders kitaplarındaki soruların eleştirel düşünmeye katkısı bu verilere dayanılarak açıklanmaya çalışılmıştır. Araştırmanın katılımcı grubu her sınıf düzeyinde dört öğretmenden oluşmaktadır. Bu bağlamda toplanan veriler sınıf düzeyinde ele alınarak incelenmiştir. Her sınıf düzeyinde incelenen veriler ve bu verilerden çıkarılan ana temalar öğretmen görüşleri eşliğinde sunulmuştur.

\section{1. "Eleştirel düşünme sizin için ne ifade etmektedir?" araştırma sorusana ilişkin bulgular}

Araştırmaya katılan öğretmenlerin “Eleştirel düşünme sizin için ne ifade etmektedir?” şeklindeki soruya verdikleri cevaplara ait kod ve temalar Tablo 1.'de sunulmuştur.

Tablo 1. Birinci Görüşme Sorusuna Verilen Cevaplarda Belirlenen Temalar, Kodlar, Katılımcılar ve Frekanslar

\begin{tabular}{|c|c|c|c|}
\hline Temalar & Kodlar & Katılımcılar & Frekans \\
\hline \multirow{6}{*}{ Beceri } & Farklı bakış açısı ile bakma & $\mathrm{A} 1, \mathrm{~A} 3, \mathrm{~A} 2, \mathrm{~B} 2, \mathrm{~B} 1, \mathrm{C} 2, \mathrm{C} 3$ & 7 \\
\hline & Analitik düșünme & $\mathrm{C} 4, \mathrm{C} 2$ & 2 \\
\hline & Probleme çözme becerisi & $\mathrm{A} 2, \mathrm{~A} 4$ & 2 \\
\hline & Üst düzey düşünme & B2, B3, & 2 \\
\hline & Kendini ifade etme & $\mathrm{C} 2, \mathrm{C} 3$ & 2 \\
\hline & Zihinsel beceri & $\mathrm{B} 4, \mathrm{~B} 1$ & 2 \\
\hline \multirow{5}{*}{ Tutum } & Sorgulayıcı tutum & $\mathrm{A} 2, \mathrm{~A} 4$ & 2 \\
\hline & Düşüncelerinin farkında olma & $\mathrm{C} 1, \mathrm{C} 4$ & 2 \\
\hline & Araştırmaya yönelik dikkat & $\mathrm{A} 1, \mathrm{~A} 3, \mathrm{~A} 4$ & 3 \\
\hline & Bilgiyi özümseme & $\mathrm{B} 4, \mathrm{~B} 1, \mathrm{~B} 3$ & 3 \\
\hline & Düşünmeye sevk etme & B2, B3 & 2 \\
\hline \multirow{5}{*}{ İşlem } & İrdeleme & B2, B3, B1 & 3 \\
\hline & Analiz etme & B3,B1 & 2 \\
\hline & Değerlendirme yapma & B1, B3, B2 & 3 \\
\hline & Sorgulama & $\mathrm{C} 1, \mathrm{C} 4$ & 2 \\
\hline & Fayda zarar analizi yapma & $\mathrm{C} 1, \mathrm{C} 3$ & 2 \\
\hline
\end{tabular}

Tablo 1 incelendiğinde sınıf öğretmenlerinin büyük bir bölümünün (f:7) eleştirel düşünme becerisini farklı bakış açısı ile bakmak olarak tanımladığı görülmektedir. Birinci sınıf öğretmenleri “Eleştirel düşünme sizin için ne ifade etmektedir?” sorusuna: farklı bakış açısı, probleme çözme becerisi, sorgulayıcı tutum, araştırmaya yönelik dikkat başlıkları çerçevesinde görüş bildirdikleri görülmüştür. Sınıf öğretmenlerinin eleştirel düşünmeyi üst düzey bir beceri olarak gördükleri ve zihinsel bir süreç olarak tanımlayabildikleri görülmektedir. Öğretmenler ayrıca eleştirel düşünme 
becerisini sahip bireyleri daha sorgulayıcı bireyler olarak görmektedirler. Katılımcılardan A2: "Eleştirel düşünme, insanların sorularla olayları sorguladıkları ve farklı bakış açısı kazandlklart bir beceridir. Ayrıca bu beceri ile insanlar herhangi bir konuyu pozitif ve negatif yönleri ile bütün olarak ele almaktadırlar." şeklinde eleştirel düşünme becerisini açıklamaya çalışmıştır.

İkinci sınıf öğretmenleri ise birinci görüşme sorusuna zihinsel beceri, farklı bakış açısı, düşünmeye sevk etme, irdeleme, analiz ve değerlendirme yapma, bilgiyi özümseme, üst düzey düşünme başlıkları çerçevesinde görüş bildirerek eleştirel düşünme becerisini tanımlamışlardır. Öğretmenlerde eleştirel düşünmenin bu çağrışımları yapması eleştirel düşünme becerisinin öğretmenler tarafından doğru bir şekilde tanımlandığını göstermektedir. Eleştirel düşünmenin özellikle bireylerde ortaya çıkardığı somut davranışlar çerçevesinde verilen örnekler bu becerinin doğru tanımlandığı tezini desteklemektedir. Katılımcılardan B4: “ Eleştirel düşünme olay ya da durumları olduğu gibi kabul etmeyip onları eleştirip yargılayıcı bakış açısı ile bakabilmek becerisidir." şeklinde eleştirel düşünme becerisini tanımlamaya çalışmıştır.

Tablo 1. incelendiğinde üçüncü sınıf öğretmenlerinin eleştirel düşünme becerisini; analitik düşünme, sorgulama, fayda zarar analizi yapma, farklı bakış açısı ile bakma, düşüncelerinin farkında olma, kendini ifade etme başlıkları çerçevesinde tanımlamaya çalıştıkları görülmektedir. Öğretmenler zihinsel süreçlerinin farkında olan ve sorgulayan insanların eleştirel düşünme becerisine sahip olduklarını belirtmişlerdir. Öğretmenler bu beceriyi başkalarının hayatlarına olan katkıları bağlamında da ele alarak tanımlamışlarıdır. Katılımcılardan C1: "Eleştirel düşünme karşımıza çıkan herhangi bir olay ya da fikirle ilgili kendi düşüncemizi ortaya koyabilme ve bunun doğruluğunun ya da yanlışlı̆̆ının bize săglayacă̆ı katklyı ya da dezavantajı ortaya koyabilme becerisidir." şeklinde eleştirel düşünme becerisini tanımlamaya çalışmıştır. Araştırmaya katılan öğretmenlerin genel olarak eleştirel düşünme becerisi hakkında literatürde yer alan tanımlar ile benzer bir anlayış benimsedikleri görülmüştür.

\section{2. "Hayat Bilgisi ders kitaplarında yer alan soruların öğrencilerin eleştirel düşünme becerisine katkısı hakkında ne düşünüyorsunuz ?" araştırma sorusana ilişkin bulgular:}


Araştırmaya katılan öğretmenlerin "Hayat Bilgisi ders kitaplarında yer alan soruların öğrencilerin eleştirel düşünme becerisine katkısı hakkında ne düşünüyorsunuz ?"'şeklindeki soruya verdikleri cevaplara ait kod ve temalar Tablo 2.'de sunulmuştur.

Tablo 2. İkinci Görüşme Sorusuna Verilen Cevaplarda Belirlenen Temalar, Kodlar, Katılımcılar ve Frekanslar

\begin{tabular}{|c|c|c|c|}
\hline Temalar & Kodlar & Katılımcılar & Frekans \\
\hline \multirow{8}{*}{$\begin{array}{c}\text { Fayda } \\
\text { Düzeyine } \\
\text { Göre }\end{array}$} & $\begin{array}{l}\text { Eleştirel düşünmeye } \\
\text { yönlendiriyor }\end{array}$ & $\mathrm{A} 2, \mathrm{~A} 3, \mathrm{~A} 4$ & 3 \\
\hline & $\begin{array}{l}\text { Eleştirel düşünmeye olumlu } \\
\text { katk1 sağllyor }\end{array}$ & $\mathrm{A} 3, \mathrm{~A} 4$ & 2 \\
\hline & $\begin{array}{l}\text { Farklı bakış açısı } \\
\text { kazandırıyor }\end{array}$ & $\mathrm{A} 2, \mathrm{~A} 4$, & 2 \\
\hline & $\begin{array}{l}\text { Gözlem yapmaya } \\
\text { yönlendiriyor }\end{array}$ & $\mathrm{A} 2, \mathrm{~A} 4$ & 2 \\
\hline & $\begin{array}{l}\text { Eleştirel düşünemeye } \\
\text { yönlendirmiyor }\end{array}$ & $\begin{array}{c}\mathrm{A} 1, \mathrm{~B} 1, \mathrm{~B} 2, \mathrm{~B} 3, \mathrm{~B} 4, \\
\mathrm{C} 1, \mathrm{C} 3\end{array}$ & 7 \\
\hline & $\begin{array}{l}\text { Farklı bakış açısı } \\
\text { kazandırmıyor }\end{array}$ & $\mathrm{B} 3, \mathrm{~B} 4, \mathrm{C} 1, \mathrm{C} 2$ & 4 \\
\hline & $\begin{array}{l}\text { Sadece bilgiyi hatırlamaya } \\
\text { yönelik }\end{array}$ & $\mathrm{B} 2, \mathrm{C} 1, \mathrm{C} 2, \mathrm{C} 3$ & 4 \\
\hline & $\begin{array}{l}\text { Üst düzey düşünmeye } \\
\text { yönlendirmiyor }\end{array}$ & $\mathrm{B} 2, \mathrm{~B} 3$ & 2 \\
\hline \multirow{2}{*}{$\begin{array}{c}\text { Öğrenci } \\
\text { Seviyesine } \\
\text { Göre }\end{array}$} & $\begin{array}{l}\text { Öğrenci seviyesine uygun } \\
\text { değil }\end{array}$ & $\mathrm{B} 1, \mathrm{~B} 3, \mathrm{~B} 4, \mathrm{C} 1, \mathrm{C} 2, \mathrm{C} 3$ & 6 \\
\hline & Öğrenci seviyesine uygun & $\mathrm{A} 3, \mathrm{~A} 2, \mathrm{~A} 4, \mathrm{C} 4$ & 4 \\
\hline
\end{tabular}

Sınıf öğretmenlerinin büyük bir kısmı, Hayat Bilgisi ders kitabındaki soruların öğrencileri eleştirel düşünmeye yönlendirmediğini (f:7) ve soruların öğrenci seviyesine uygun olmadığını (f:6) belirtmişlerdir. Birinci sınıf öğretmenleri ikinci görüşme sorusuna; eleştirel düşünmeye yönlendiriyor, eleştirel düşünmeye olumlu katkı sağlıyor, farklı bakış açısı kazandırıyor, gözlem yapmaya yönlendiriyor, öğrenci seviyesine uygun başlıkları çerçevesinde görüş bildirdikleri görülmüştür. Öğretmenler genel olarak soruları öğrenci seviyesine uygun olarak gördüklerini ve seviyelerine uygun olacak şekilde eleştirel düşünmeye yönlendirdiğini (A1 hariç) belirtmişlerdir. A1 katılımcısı soruların öğrencileri yeterli düzeyde eleştirel düşünmeye yönlendirmediğini belirtmiştir. Bunun gerekçesi olarak da bazı soruların öğrencilerin hayatları ile ilişkilendirilmemesini sunmuştur. Birinci sınıf öğrencilerinin daha çok somut düşünme döneminde olduğunu vurgulayan öğretmenler bu becerinin kazandırılmasına yönelik hazırlanmış olan soruları 
önemsediklerini ifade etmişlerdir. Hayat Bilgisi ders kitabında yer alan soruların etkinliklerin gölgesinde kaldığını belirten A2, eleştirel düşünme becerisinin çok küçük yaşlardan itibaren kazandırılmasının önemli olduğunu belirtmiştir. Katılımcılardan A3: "Sorulara baktığımda genelde araştırmaya yönelik, ezberden uzak, daha çok somut proje çalışmaları tarzında oldukların görmekteyim. Sorular ögrrencilerin seviyelerine uygun hazırlanmış. Bu tarz sorular ögrrencileri eleştirel düşünmeye yönlendiriyor. ”şeklinde görüşünü bildirmiştir.

İkinci sınıf öğretmenleri ikinci görüşme sorusuna: eleştirel düşünemeye yönlendirmiyor, üst düzey becerilere yönelik değil, farklı bakış açısı kazandırmıyor, bilgiyi hatırlamaya yönelik, sadece bilgiyi ölçüyor başlıkları çerçevesinde görüş bildirmişlerdir. Öğretmenler soruların öğrencileri eleştirel düşünme becerisinden ziyade ezbere yönlendirdiği belirtmişlerdir. Öğretmenler kitapta yer alan soruların öğrencileri eleştirel düşünmeye yönlendirmediğini ve konularda geçen kelimeleri buldurmaya yönelik olduğunu ifade etmişlerdir. Hatta bazı soruların öğrencileri kopyala yapıştır şeklinde mekanikleştirdiği görüşündedirler. Soruların konulardaki teknik bilgi kısmına daha çok yoğunlaştığını belirten öğretmenler bu durumun üst düzey becerilerin gelişimine pek katk1 sağlamadığını belirtmişlerdir. Katılımcılardan B2: "Hayat bilgisi ders kitabındaki sorular eleştirel düşünmeden ziyade konu hakkında bilgilerinin ne olduğu, bilgiye yönelik sorulardan oluşuyor. Çocuklarin analiz ve sentez yapabilecekleri üst düzey becerilere yönelik sorular değil." şeklinde görüşünü bildirmiştir.

Üçüncü sınıf öğretmenleri ikinci görüşme sorusuna; ders kitabındaki soruların düzeyi yetersiz, farklı bakış açısı kazandırmıyor, daha çok bilgi düzeyinde, eleştirel düşünmeye yönlendirmiyor başlıkları çerçevesinde görüş bildirdikleri görülmüştür. Üçüncü sınıf öğretmenleri genel olarak soru düzeylerinin sınıf seviyesinin çok altında olduğundan şikâyet etmişlerdir (C4 hariç). $\mathrm{Bu}$ sebepten dolayı soruların eleştirel düşünmeden öteye ezbere yönlendirdiğini ifade etmişlerdir. Öğretmenler soruların daha çok hatırlatmaya yönelik hazırlandığını ve bu nedenle öğrencileri eleştirel düşünmeye yönlendirmediği görüşündedirler. Eleştirel düşünmenin üst düzey bir beceri olduğunu vurgulayan öğretmenler bu tarz soruların bu konuda yetersiz kaldığını belirtmişlerdir. C4 katılımcısı soruların düzeyinin öğrencilere uygun olduğunu belirtmiş ve yeterli düzeyde gördüğünü ifade etmiştir. C4 katılımcısı ayrıca kitaptaki soruların mevcut düzeyinin üzerindeki soruların öğrencileri çok zorlayacağını belirtmiştir. Sınıf öğretmenlerinin soruların düzeyine yönelik yoğun eleştirilerinin olduğu görülmüştür. Katılımcılardan $\mathrm{C} 1$ : "Hayat bilgisi ders 
kitabındaki sorular öğrencileri eleştirel düşünmeye yönlendirmiyor. Sorular eleştirel düşünmeyi kazandırmada basit kalıyor. Soruların bu anlamda genel olarak çok iyi olduğunu düşünmüyorum. “ olarak görüş bildirmiştir.

\section{3. "Hayat Bilgisi ders kitaplarında yer alan soruların öğrencilerin eleştirel düşünme becerisine katkısının artırılmasına yönelik önerileriniz nelerdir?" araştırma sorusana ilişkin bulgular:}

Araştırmaya katılan öğretmenler Hayat Bilgisi ders kitaplarında yer alan soruların öğrencilerin eleştirel düşünme becerisine olan katkısı hakkında görüşlerini ifade etmişlerdir. Bu görüşler incelendiğinde öğretmenlerin sorular hakkında farklı beklentilerinin olduğu görülmektedir. Ders kitabında yer alan bu soruların öğrencilerin eleştirel düşünme becerisine katkısı hakkında öğretmenlerin beklenti ve önerilerinin ne olduğunu belirlemek amacı ile öğretmenlere görüşme formunda yer alan son soru sorulmuştur. Sınıf öğretmenlerinin "Hayat Bilgisi ders kitaplarında yer alan soruların öğrencilerin eleştirel düşünme becerisine katkısının artırılmasına yönelik önerileriniz nelerdir?" şeklindeki soruya verdikleri cevaplara ait kod ve temalar Tablo 3.'de sunulmuştur.

Tablo 3. Üçüncü Görüşme Sorusuna Verilen Cevaplarda Belirlenen Temalar, Kodlar, Katılımcılar ve Frekanslar

\begin{tabular}{clcc}
\hline Temalar & \multicolumn{1}{c}{ Kodlar } & Katılımcılar & Frekans \\
\hline \multirow{2}{*}{ Soru sayı1s1 } & Soru sayıs1 arttırılmalı & $\begin{array}{c}\text { A1, A2, A3, B1, B2, B3, } \\
\text { C1, C2, C3 }\end{array}$ & 9 \\
\hline & Daha somut düzeyde & A1, A2, A4, B2, B3, C2, & 7 \\
\cline { 2 - 4 } & Caha anlaş1labilir olmalı & B4, C3 & 2 \\
\cline { 2 - 4 } $\begin{array}{c}\text { Soru içeriği } \\
\text { ve düzeyi }\end{array}$ & Soru düzeyi yükseltilmeli & C1, C2, C3, C4 & \\
\cline { 2 - 4 } & $\begin{array}{l}\text { Sorular gerçek hayat ile } \\
\text { ilişkilendirilmeli }\end{array}$ & A1, A3, A4, B1, B3, B4, & 9 \\
\cline { 2 - 4 } & Empati kurdurmalı & C2, C2, C3 & 3 \\
\hline
\end{tabular}

Tablo 3 incelendiğinde sınıf öğretmenlerinin büyük bir kısmı, soru sayısının artırılması (f: 9) ve soruların gerçek hayat ile ilişkilendirilmesi (f: 9) gerektiği konusunda görüş bildirmişlerdir. Birinci sınıf öğretmenleri üçüncü görüşme sorusuna: soru sayısı arttırılmalı ve sorular gerçek hayat ile ilişkilendirilmeli başlıkları etrafında görüş bildirdikleri görülmüştür. Öğretmenler kitapta yer alan soru sayısının çok az olduğunu ve bunun artırılması gerektiğini belirtmişlerdir. Öğretmenler soru 
sayıs1 artırıldığında çocukların daha fazla düşünmeye sevk edilebileceğini öngörmektedirler. Öğretmenler ayrıca kitaptaki soruların daha somut düzeyde, gerçek hayatla ilişkilendirmesinin fayda sağlayacağını belirtmişlerdir. Bu sağlandığında kendi sınıflarındaki öğrencilerin olay ve durumlar karşısında daha eleştirel düşünebileceklerini belirtmişlerdir. Katılımcılardan A1: "Ders kitabindaki soru sayısı artırabilir, genelde kitapta tek soru ile konular kapatıllyor. Bu sayl artırılabilir. Sorular daha somut, gündelik hayat ile ilişkili olması gerekir. "şeklinde görüşünü aktarmıştır.

İkinci sınıf öğretmenleri üçüncü görüşme sorusuna; sorular daha anlaşllabilir olmalı, günlük hayatla ilişkili olmalı ve soru sayısı artırılmalı başlıkları etrafında görüş bildirmişlerdir. Öğretmenlerden B4, sadece soruların değil müfredattın da hep birlikte ele alınarak bir bütünlük içerisinde değiştirilmesi gerektiğini belirtmiştir. Katılımcılardan B4: "Müfredatın öncelikle çocukları eleştirel düşünme becerisine hazırlayabilecek bir şekilde değiştirilmesi gerekir. Ders kitapları da bu şekilde hazırlanmalı. Biz çocuğa bilgiyi yorumlama becerisi katmalıyız." şeklinde görüş bildirmiştir. Öğretmenlerin tamamı kitaplarda yer alan soru sayısının az olduğunu düşünmektedirler. Öğretmenler daha fazla soru ile öğrencilerin daha fazla eleştirel düşünmeye yönlendirilebileceğini belirtmişlerdir. Ayrıca öğretmenler sınıf seviyesine göre daha anlaşılır ve günlük hayat ile ilişkili soruların daha fazla katkı sağlayacağını düşünmektedirler. Katılımcılardan B3: “ Bana göre sorular gündelik hayata uygun, anlaşılır sorular olmalı. Hayat Bilgisi dersinde ögrenciler sıkılmamalı. Soru sayısını az buluyorum. Bu soruların sayısının artması gerekir." şeklinde görüş bildirmiş̧ir.

Üçüncü sınıf öğretmenleri üçüncü görüşme sorusunu; soru sayısı artırılmalı, soru düzeyi yükseltilmeli, sorular öğrencilere empati kurdurmalı başlıkları etrafında görüş bildirerek cevaplamışlardır. Öğretmenlere göre çocukların soruları benimsemeleri gerekiyor ve bunu yapabilmeleri için çevrelerindeki olaylar ekseninde soruların sorulması gerektiğini belirtmişlerdir. Yakın çevreden uzak çevreye doğru soruların hazırlanması halinde soruların eleştirel düşünmeye daha fazla katkı sağlayacağını belirtmişlerdir. Öğretmenler ayrıca soru sayısının az olduğunu ve bu sayının artırılması gerektiğini belirtmişlerdir. Katılımcılardan $\mathrm{C} 1$ : "Soruların eleştirel düşünme becerisi kazandırabilmesi için soru saylsı artırlabilir. Sorular öğrencileri farklı düşünmeye yönlendirecek sorular olmalı ve yakın çevrelerindeki örnek olaylardan yola çıkılarak sorular sorulabilir. " olarak görüş bildirmiştir. 


\section{Tartışma, Sonuç ve Öneriler}

Bu çalışma ile Hayat Bilgisi ders kitaplarında yer alan soruların eleştirel düşünmeye katkısının öğretmen görüşlerine göre incelenmesi amaçlanmıştır. $\mathrm{Bu}$ amaç doğrultusunda ilkokul birinci, ikinci ve üçüncü sınıf öğretmeleri ile görüşmeler gerçekleştirilmiş ve ele edilen bulgular açıklanmaya çalışılmıştır. Eleştirel düşünme becerisi hakkında görüşleri alınacak kişilerin öncelikle bu konuda yeterli bilgi donanımına sahip olması beklendiğinden öncelikle katılımcıların eleştirel düşünmeyi nasıl algıladıkları belirlenmeye çalışılmıştır.

Araştırmaya katılan birinci sınıf öğretmenlerinin eleştirel düşünmeyi; farklı bakış açısı, probleme çözme becerisi, araştırmaya yönelik dikkat ve sorgulayıcı tutum başlıkları çerçevesinde tanımladıkları görülmüştür. İkinci sınıf öğretmenleri ise eleştirel düşünmeyi; zihinsel beceri, farklı bakış açısı, düşünmeye sevk etme, irdeleme, analiz ve değerlendirme yapma, bilgiyi özümseme, üst düzey düşünme başlıkları çerçevesinde tanımlamışlardır. Üçüncü Sınıf öğretmenleri eleştirel düşünmeyi; analitik düşünme, sorgulama, fayda zarar analizi yapma, farklı bakış açısı ile bakma, düşüncelerinin farkında olma, kendini ifade etme başlıkları çerçevesinde tanımlamışlardır. Bu tanımlar literatürde yer alan uzman tanımları (Cüceloğlu, 1994:99; Reed, 1998: 14; Akınoğlu, 2001: 16; Gündoğdu, 2009:62; Schreglmann, 2011: 29) ile örtüşmektedir. Her ne kadar öğretmenlerin eleştirel düşünmeyi tüm yönleri ile ele almadıkları görülse bile genel anlamda uzman görüşleri ile örtüşen birçok ortak noktanın olduğu görülmektedir. Öğretmenlerin eleştirel düşünme hakkındaki bu görüşleri öğrencilere bu becerinin kazandırılması ve ders kitaplarında yer alan soruların eleştirel düşünmeye uygunluğunun belirlenmesi açısından çok önemlidir.

Araştırmaya katılan birinci sınıf öğretmenlerine göre Hayat Bilgisi ders kitaplarında yer alan sorular, öğrencileri eleştirel düşünemeye yönlendirmektedir. Öğretmenlere göre birinci sınıf Hayat Bilgisi ders kitabında yer alan sorular öğrenciyi sorgulamaya, empati kurmaya, analiz ve sentez yapmaya yönlendirmektedir. Araştırmaya katılan ikinci sınıf öğretmenleri ise Hayat Bilgisi ders kitaplarında yer alan soruların, öğrencileri eleştirel düşünemeye yönlendirmediğini, öğrencilere üst düzey düşünce becerisi kazandırmadığını ve bilgiyi ezberlemekten öteye geçmediğini belirtmişlerdir. İkinci sınıf öğretmenlerine göre Hayat Bilgisi ders kitabındaki soruların büyük bir kısmı metindeki olaylar hakkında öğrencileri düşünmeye, fikir üretmeye yönlendirecek ve eleştirel 
düşünmeye yönlendirecek şekilde hazırlanmıştır. Araştırmaya katılan üçüncü sınıf öğretmenleri, Hayat Bilgisi ders kitabında yer alan soruların, daha çok bilgi düzeyinde, farklı bakış açısı kazandırmayan ve eleştirel düşünmeye yönlendirmeyen sorulardan oluştuğunu belirtmişlerdir. Üçüncü sınıf öğretmenlerine göre kitapta yer alan sorular sınıf seviyesine göre çok basit ve yüzeysel sorulardan oluşmaktadır. Hayat Bilgisi ders kitabında yer alan soruların öğrencileri ezberciliğe yönlendirmeyen, problem çözme, sorgulama ve nihayetinde eleştirel düşünme becerisi kazandıran sorulardan oluşturulması beklenmektedir (Gündoğdu, 2009:63). Eleştirel düşünme ile bilinenin ötesine geçilerek, deneyim, arayış ve atılım olanakları ile eğitim programlarının hedeflerine ulaşmasına katkı sağlanmalıdır (Kürüm, 2003:144). Bu nedenle kitaplar da yer alan sorular öğrencilerin fikirlerini açığa çıkarmalı, düşünmeye sevk etmeli ve merakın ortaya çıkarılmasına çalışmalıdır (Büyükalan, 2004:7).

Araştırmada katılımcılar Hayat Bilgisi ders kitaplarında yer alan soruların öğrencilerin eleştirel düşünme becerisine olan katkısının artırılmasına yönelik önerilerde bulunmuşlardır. Birinci sınıf ögretmenleri Hayat Bilgisi ders kitaplarında yer alan soru sayısının az olduğunu mevcut soru sayısının artırılmasının öğrencilerin eleştirel düşünme becerisi kazanmasına daha fazla katkı sağlayacağını belirtmişlerdir. Araştırma sürecinde ikinci ve üçüncü sınıf öğretmenlerinin de Hayat Bilgisi ders kitaplarında yer alan sorular hakkında benzer önerilerde bulundukları görülmüştür. Şüphesiz ki öğrencilerin ön bilgileri, yaşantıları dikkate alınarak sorulacak sorular öğrencinin yeni bilgileri inceleme, onlar üzerinde düşünme ve zihninde yapılandırmasına katkı sağlayacaktır. $\mathrm{Bu}$ nedenle öğrencileri eleştirel düşünmeye yönlendirecek soruların, öğrencilerin ön bilgilerini, yakın çevrelerini, bireysel ihtiyaçlarını ve günlük yaşantılarını dikkate alması gerekir. Bu şekilde hazırlanacak sorular öğrencilerin olayları daha rahat kavrayarak irdelemelerine imkân tanıyacaktır. Çünkü eğitim sürecinde kazanılan bilgiler günlük yaşamdaki olaylarla ilişkilendirilebildiği ölçüde kalıcı olurlar ve karşılaşılan yeni durumları yorumlamada daha kolay kullanılabilirler (Özden, 2003:56). Diğer yandan ders kitaplarında yer alacak soru sayısı belirlenirken tutarlı bir yaklaşım sergilenmelidir. Bu bağlamda öğrencilere eleştirel düşünme becerisini kazandırılacak nitelikli ve kapsamlı soruların hazırlanması önemlidir. Hayat bilgisi ders kitaplarında bu manada soru sayısının artırılması belirlenen hedeflere ulaşılması noktasında kolaylık sağlayabilir. 


\section{Kaynakça}

ALADAĞ, S. (2016). Hayat Bilgisi: Tanımı, Amacı ve Doğası. S. Güven ve S. Kaymakçı (Ed.), Hayat Bilgisi Öğretimi İçinde (s. 1-22). Pegem Akademi, Ankara, 552s.

AKÇAY, H.ve KAPICI, H. Ö. (2016). Hayat Bilgisi Öğretim Programı Ve Temel Beceriler. S. Güven ve S. Kaymakçı (Ed.), Hayat Bilgisi Öğretimi İçinde (s.111-132). Pegem Akademi, Ankara, 552s.

AKINOĞLU, O. (2001). "Eleştirel Düşünme Becerilerini Temel Alan Fen Bilgisi Öğretiminin Öğrenme Ürünlerine Etkisi” Doktora Tezi, Hacettepe Üniversitesi / Sosyal Bilimler Enstitüsü, Ankara.

AYBEK, B. (2010). Örneklerle Düşünme ve Eleştirel Düşünme. Nobel Kitapevi, Adana,114s.

BÜYÜKALAN, F. S. (2002). "Soru-Cevap Yöntemine İlişkin Öğretimin Öğretmenlerin Soru Sorma Düzeyi ve Tekniklerine Etkisi”, Doktora Tezi, Gazi Üniversitesi/ Eğitim Bilimleri Enstitüsü, Ankara.

CÜCELOĞLU, D. (1994). İyi Düşün Doğru Karar Ver, Sistem Yayınc1lık, İstanbul, 404s.

ERSOY, E. ve BAŞER, N. (2011). “İlköğretim İkinci Kademede Eleştirel Düşünmenin Yeri”. Adnan Menderes Üniversitesi Eğitim Fakültesi Eğitim Bilimleri Dergisi, 2(1), 1-10.

GÜNDOĞDU, H. (2009). "Eleştirel Düşünme Ve Eleştirel Düşünme Öğretimine Dair Bazı Yanılgılar”, Celal Bayar Üniversitesi, Sosyal Bilimler Dergisi, 7 (1), 57-74.

GÜNGÖRDÜ, Ersin (2002). İlköğretimde Hayat Bilgisi ve Sosyal Bilgiler Öğretimi. Nobel Yayınları. Ankara, 181s.

HALPERN, D. F. (2003). Thoughts and Knowledge: An Introduction to Critical Thinking,: Lawrence Erlbaum Associates, New Jersey-London, 656s.

HÖKELEKLİ, H. (2010). "Modern Eğitimde Yeni Bir Paradigma: Değerler Eğitimi”. Eğitime Bakış Dergisi, 6 (18), 4-10. 
KÜRÜM, D. (2003). "Eleştirel Düşünme ve Öğretimi”. Anadolu Üniversitesi Eğitim Fakültesi Dergisi, 13 (2), 141- 158.

MARRAPODİ, J. (2003). "Critical Thinking And Creativity: An Overview And Comparison Of The Theories". Critical Thinking And Adult, 14-41

MILES, M. B. ve HUBERMAN, A.M. (1994). Qualitative Data Analysis : An Expanded Sourcebook. SAGE Publications, Calif, 408s.

MEB (2018). Matematik Dersi Öğretim Programı (İlkokul ve Ortaokul 1, 2, 3, 4, 5, 6, 7 ve 8. Sinıflar), Ankara. 8s.

REED, H. J. (1998). Effect Of A Model For Critical Thinking On Student Achievement İn Primary Source Document Analysis And İnterpretation, Argumentative Reasoning, Critical Thinking Dispositions, And History Content İn A Community College History Course. Retrieved from Dissertations \& Theses: Full Text database (AAT 9911510).

SAĞLAM, H. İ. (2015). Toplum, Birey Ve Doğaya Bütüncül Bakış: Hayat Bilgisi. M. Gültekin (Ed.), Hayat Bilgisi Öğretimi İçinde (ss. 1-14). Nobel Yayınları, Ankara, 274s.

SCHREGLMAN, S. (2011). "Konu temelli eleştirel düşünme öğretiminin öğretmen adaylarının akademik başarı, eleştirel düşünme eğilimine ve düzeyine olan etkisi”, Yüksek lisans Tezi, Çukurova Üniversitesi / Sosyal Bilimler Enstitüsü, Adana.

ŞIMSSEK, S. (2005). “Örnek Olaya Dayalı Öğretimin İlköğretim Hayat Bilgisi Dersinde Akademik Başarıya ve Öğrenmede Kalıcılığa Etkisi”, Doktora Tezi, Eskişehir Anadolu Üniversitesi/Eğitim Bilimleri Enstitüsü, Eskişehir.

ÖZDEN, Y. (2003). Öğrenme ve Öğretme, Pegem Yayınc1lık, Ankara, 270s.

YAMAN, E. (2014). Değerler Eğitimde Yeni Ufuklar, Akçağ Yayınları, Ankara, 254s.

YILDIRIM, A. ve ŞİMȘEK, H. (2005) Sosyal Bilimlerde Nitel Araştırma Yöntemleri (2. baskı). Seçkin Yayıncılık, Ankara, 432s. 
YILDIRIM, H.İ.ve YALÇIN, N. (2008). "Eleştirel Düşünme Becerilerini Temel Alan Fen Eğitimin Fen Bilgisi Öğretmen Adaylarının Problem Çözme Becerilerine Etkisi”. Gazi Üniversitesi Gazi Eğitim Fakültesi Dergisi, 28(3), 165-187.

WIMPENNY, P. ve GASS, J. (2000). "Interviewing İn Phenomenology And Grounded Theory: İs There A Difference?", Journal of Advanced Nursing, 31(6), 1485-1492. 